\title{
Treatment of Iron Deficiency in Women
}

\section{Therapeutische Aspekte des Eisenmangels bei der Frau mit Menstruation}

Authors

Affiliations
C. Breymann ${ }^{1}$, T. Römer², J. W. Dudenhausen ${ }^{3,4}$

${ }^{1}$ Forschung, Geburtshilfe, Universitätsspital Zürich

${ }^{2}$ Gyn/Gebh., Evang. Krankenhaus Köln-Weyertal

${ }^{3}$ Geburtsmedizin, Charité-Universitätsmedizin Berlin

${ }^{4}$ Ob/Gyn, Sidra Medical and Research Center, Doha, Qatar

\begin{abstract}
Key words
- biomarker

- epidemiology

- uterus

Schlüsselwörter

- Biomarker

- Epidemiologie

- Uterus
\end{abstract}

\section{Abstract \\ $\nabla$}

Iron deficiency with and without anaemia is a common cause of morbidity, particularly in women. Iron deficiency is generally the result of an imbalance between iron loss and iron absorption. In women with symptoms suspicious for iron deficiency, it is important to confirm or exclude the suspicion using proper tests. The use of serum ferritin levels is considered the gold standard for diagnosis. Although the ideal ferritin levels are not unknown the current consent is that levels $<40 \mathrm{ng} / \mathrm{ml}$ indicate iron deficiency, which needs to be treated in symptomatic patients. However, symptoms can already occur at ferritin levels of $<100 \mathrm{ng} / \mathrm{ml}$ and treatment must be adapted to the individual patient. Iron supplementation is only indicated in symptomatic patients diagnosed with iron deficiency whose quality of life is affected. It is important to treat iron deficiency together with its causes or risk factors. For example, blood loss from hypermenorrhea should be reduced. Women also need to receive information about the benefits of an iron-rich diet. If oral treatment with iron supplements is ineffective, parenteral iron administration is recommended.

accepted $\quad 30.1 .2013$

\section{Bibliography}

DOI http://dx.doi.org/

10.1055/s-0032-1328271

Geburtsh Frauenheilk 2013; 73 :

256-261 @ Georg Thieme

Verlag KG Stuttgart · New York . ISSN 0016-5751

\section{Correspondence}

Prof. Joachim Dudenhausen

Sidra Medical and Research

Center

PO Box 26999

Doha

Qatar

Joachim.Dudenhausen@

charite.de

\section{Introduction}

It is well known that iron deficiency is one of the most common nutritional deficiencies worldwide. The physical consequences and symptoms depend on the duration and severity of the iron deficiency. Countries with chronic malnutrition report a high prevalence of people with iron deficiency anaemia (50-80\%). In contrast, in countries where nutrition is generally sufficient, iron

\section{Zusammenfassung \\ $\nabla$}

Eisenmangel mit und ohne Anämie sind häufige Ursachen für Morbidität und Organdysfunktionen, vor allem bei Frauen. Gründe hierfür ist im Allgemeinen ein Missverhältnis zwischen Eisenverlusten und Eisenaufnahme. Bei Beschwerden, die auf einen Eisenmangel hinweisen, muss dieser mit den korrekten Methoden diagnostiziert oder ausgeschlossen werden. Als Goldstandard hierfür gilt der Serumferritinwert. Der ideale Zielwert für Ferritin ist nicht bekannt, nach dem derzeitigen Wissenstand sind Werte $<40 \mathrm{ng} / \mathrm{ml}$ hinweisend für einen Eisenmangel und sollten bei entsprechenden Symptomen behandelt werden. Beschwerden können allerdings bei Ferritinwerten bis $\mathrm{zu}<100 \mathrm{ng} / \mathrm{ml}$ gefunden werden und auch individuell behandelt werden. Eine Therapie mit Eisen sollte nur bei nachgewiesenem Eisenmangel und Symptomen bzw. Leidensdruck oder verminderter Lebensqualität begonnen werden. Dabei soll der Eisenmangel per se und die Ursachen bzw. Risikofaktoren behandelt werden. Gegebenenfalls müssen uterine Blutverluste vermindert werden. Schließlich sollte die Frau über Möglichkeiten und Grenzen der „eisenreichen“ Ernährung instruiert werden. Bei ungenügender Wirksamkeit von oralen Eisenpräparaten ist die parenterale Eisengabe eine Erfolg versprechende, wichtige Alternative der ersten Wahl.

\section{Einleitung}

Es ist bekannt, dass Eisenmangel zu den weltweit häufigsten nutritiven Mangelzuständen gehört, wobei die körperlichen Folgen und Symptome von der Dauer und Schwere des Eisenmangels abhängen. Während Länder mit chronischer Unterernährung eine hohe Prävalenz von Menschen mit Eisenmangelanämie aufweisen (50-80\%), findet man in Ländern mit normaler Ernährung häufig Eisenmangel- 
deficiency may often be present without anaemia (prevalence of up to $20 \%$ ) [1,16]. The prerequisites for successful treatment are a correct diagnosis of iron deficiency, the choice of an effective iron preparation, and treatment of the causes of the iron deficiency. Definitions of iron deficiency and anaemia are given in $\bullet$ Table 1.

\section{Symptoms of Iron Deficiency and Treatment \\ $\nabla$}

The main reason for prescribing iron therapy is iron deficiency symptoms which affect the patient's quality of life. A therapeutic use of iron preparations to treat persons with low stores but without symptoms is not recommended. Symptoms of iron deficiency (fatigue, headache, hair loss, poor concentration, generally reduced performance) are the result of iron deficiency in various enzyme systems (oxidoreductase, mono-oxidase, dioxygenase) and of reduced mitochondrial activity in body cells [2]. Several placebo-controlled studies have demonstrated a positive effect of iron administration for specific symptoms [2,3]. However the effect of iron on ferritin levels, the figure used to measure iron reserves, is not directly correlated to the amount of iron administered. It is also important to be aware that while certain symptoms such as fatigue can indicate iron deficiency, they do not constitute proof of it. Persons without iron deficiency can also suffer from fatigue just as persons with iron deficiency do. The sensitivity of the symptom "chronic fatigue" for iron deficiency (ferritin $<15 \mathrm{ng} / \mathrm{ml}$ ) is only $20 \%$. If symptoms appear to indicate iron deficiency, such a suspicion should always be verified using specific tests.

\section{Diagnosis \\ $\nabla$}

\section{Haemoglobin and erythrocyte indices}

Although in clinical practice haemoglobin levels are often the first indication of iron deficiency, it is important to note that both haemoglobin levels and the erythrocyte indices MCV and $\mathrm{MCH}$ have a very low sensitivity and specificity for the detection of iron deficiency and usually only show significant changes in the end phases of iron deficiency. If there is a suspicion of iron deficiency, more specific and more sensitive tests should be used to detect iron deficiency at an early stage and prevent iron deficiency anaemia.

\section{Ferritin}

The measurement of serum ferritin levels offers the highest sensitivity and specificity for the detection of iron deficiency $[4,5]$. Ferritin levels $<20 \mu \mathrm{g} / \mathrm{l}$ are proof of iron deficiency irrespective of haemoglobin levels. Ferritin levels of $20-50 \mu \mathrm{g} / \mathrm{l}$ are viewed as a grey area, i.e., even though limited iron stores are still present at these levels, it is assumed that a certain percentage of women will already be symptomatic with these serum ferritin levels. If ferritin levels are within normal ranges (> 50 $\mu \mathrm{g} / \mathrm{l}$ ), iron deficiency anaemia can be excluded unless the patient has concurrent infection. In this case, ferritin levels may be false normal as apoferritin is an acute phase protein similar to C-reactive protein and apoferritin levels increase when infection or inflammation (e.g. postoperative inflammation) is present. Serum ferritin levels only correctly represent iron stores 6 weeks after surgery or after giving birth.

If there is a suspicion that iron deficiency is coupled with anaemia it is important to first exclude infection or inflammation
Table 1 Cut-off values in women.

Iron deficiency with anaemia
Hb $<120 \mathrm{~g} / \mathrm{l}$
Iron deficiency without anaemia
Fb $>120 \mathrm{~g} / \mathrm{I}$
Ferritin $<20 \mathrm{ng} / \mathrm{ml}^{*}$
Latent iron deficiency without anaemia
Hb $>120 \mathrm{~g} / \mathrm{l}$
- Ferritin $<50 \mathrm{ng} / \mathrm{ml}^{*}$
Transferrin saturation $<20 \%$

* Opinions in the literature differ regarding the highest serum ferritin cut-off value for the diagnosis of iron deficiency. Iron stores are definitively empty at ferritin levels $<20 \mathrm{ng} / \mathrm{ml}$. Levels between 20 and $50 \mathrm{ng} / \mathrm{ml}$ are considered a grey area, i.e. low or empty iron stores are possible or even probable, particularly combined with lower transferrin saturation levels.

zustände ohne Anämie (Prävalenz bis 20\%) [1,16]. Voraussetzung für eine erfolgreiche Eisentherapie ist zum einen die korrekte Diagnostik des Eisenmangels, zum anderen die Wahl effizienter Eisenpräparate und die Behandlung der Ursachen des Eisenmangels. Definitionen von Eisenmangel und Anämie sind aus $\bullet$ Tab. 1 ersichtlich.

\section{Symptome bei Eisenmangel und deren Behandlung} $\nabla$

Hauptgrund für den Einsatz der Eisentherapie sind Eisenmangelsymptome, die für die Frau einen Leidensdruck darstellen. Der therapeutische Einsatz von Eisenpräparaten zur alleinigen Korrektur niedriger Eisenspeicher ohne Symptome ist abzulehnen. Symptome bei Eisenmangel (Fatigue, Kopfweh, Haarausfall, Konzentrationsschwäche, reduzierte Leistungsfähigkeit i.A.) sind unter anderem eine Konsequenz des Eisenmangels in verschiedenen Enzymsystemen wie Oxidoreduktasen, Monooxidasen, Dioxigenasen und vor allem eine verminderte mitochondriale Aktivität in den Körperzellen [2]. Ein positiver Einfluss der Eisengabe auf spezifische Symptome konnte in verschiedenen, placebokontrollierten Studien gezeigt werden [2,3]. Dabei ist die Wirkung des Eisens in keiner direkten Korrelation mit der gegebenen Eisenmenge oder dem Ferritinwert, dem Maß für die Eisenspeicher. Wichtig ist, dass bestimmte Symptome, wie zum Beispiel Müdigkeit, lediglich ein Hinweis auf Eisenmangel sein können, aber kein Beweis dafür sind. Menschen ohne Eisenmangel können in gleichem Maße Müdigkeit aufweisen wie Menschen mit Eisenmangel. Die Sensitivität des Symptoms „chronische Müdigkeit“ für einen Eisenmangel (Ferritin $<15 \mathrm{ng} / \mathrm{ml}$ ) liegt bei lediglich 20\%. Daher muss bei Verdacht auf Eisenmangel als Ursache gewisser Probleme immer durch spezifische Tests verifiziert werden.

\section{Diagnostik \\ $\nabla$}

Hämoglobin und Erythrozytenindices

Obwohl im klinischen Alltag die Hämoglobinkonzentration meist den ersten Hinweis auf einen Eisenmangel gibt, ist zu beachten, dass sowohl der Hämoglobinwert als auch Erythrozytenindices wie MCV und $\mathrm{MCH}$ eine sehr geringe Sensitivität und Spezifität zur Detektion von Eisenmangelzuständen aufweisen und zumeist nur in der Endphase des Eisenmangels signifikante Veränderungen zeigen. Insbesondere zur Früherfassung von Eisenmangelzuständen und damit zur Prävention der Eisenmangelanämie sollten bei Verdacht spezifischere und sensitivere Tests angewendet werden. 
(CRP measurement) before drawing any definitive conclusions about the status of iron levels in a patient. In special cases, various parameters can be used to complement the diagnostic tests for iron levels.

\section{Causes of Iron Deficiency}

$\nabla$

Women have a much higher natural risk of iron deficiency compared to men. The prevalence of iron deficiency in women with regular periods is almost 10 times higher than that reported for men of the same age; moreover, it has been shown that among blood donors only women may have ferritin levels $<20 \mathrm{ng} / \mathrm{ml}$, i.e. empty iron stores. This is due to the regular loss of blood and iron during menstruation combined with an inadequate or insufficient daily nutritional supply of iron. While daily metabolic iron loss in men is $1.5 \mathrm{mg} /$ day, the figure for women is around $0.5 \mathrm{mg} /$ day higher and amounts to $2 \mathrm{mg} /$ day in women with "normal" menstruation ( $<80 \mathrm{ml} / \mathrm{month})$. In women who do not menstruate, for example after hysterectomy or menopause, iron loss per day is comparable with that of men. In women with heavy or prolonged menstruation (hypermenorrhea), blood loss can be as high as $400 \mathrm{ml}$ (!) per month, which corresponds to an iron loss of approximately $200 \mathrm{mg}$ [6,7]. Risk factors for excessive menstruation include uterine disorders such as myomas, uterine adenomyosis, endometrial hyperplasias and polyps but also coagulation disorders such as von Willebrand disease or blood platelet disorders. Given that an adult woman has around $300 \mathrm{mg}$ iron stores out of $2.3 \mathrm{~g}$ total-body iron, it is obvious that heavy menstrual bleeding will result in a depletion of iron stores. $70 \%$ of women with blood loss of more than $80 \mathrm{ml} / \mathrm{month}$ present with iron deficiency with or without anaemia.

\section{Gynaecological Bleeding as a Cause of Iron Deficiency and Iron Deficiency Anaemia

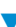

Gynaecological bleeding as the cause of iron deficiency includes recurrent hypermenorrhea, menorrhagia or metrorrhagia. These disorders are summarised by the term "heavy menstrual bleeding". It is well known since many years that increased blood loss during menstruation results in significantly higher rates of anaemia.

A study of 330 women showed that menstrual blood loss of 61$80 \mathrm{ml}$ per cycle resulted in an anaemia rate of $10.3 \%$, while menstrual blood loss of $161-240 \mathrm{ml}$ resulted in an anaemia rate of $50 \%$ [7].

Another study has shown that if iron deficiency is defined as haemoglobin $<12 \mathrm{~g} / \mathrm{dl}$ and ferritin level $<16 \mathrm{ng} / \mathrm{dl}$, the prevalence of iron deficiency anaemia is $0 \%$ if blood loss $<20 \mathrm{ml}$ but rises to $17 \%$ if blood loss is $60-80 \mathrm{ml}$ and increases to $26 \%$ when blood loss is greater than $100 \mathrm{ml}$ [6].

Gynaecological bleeding caused by disorders such as adenomyosis, myomatous uterus or endometrial hyperplasia often results in significant iron deficiency anaemia [8]. A phase III trial of hormone therapy in 231 patients with hypermenorrhea reported a mean blood loss of $640 \mathrm{ml}$ using the alkaline haematin method and a 90-day reference period (WHO). The amount of blood lost was found to be closely correlated to low haemoglobin and ferritin levels [8].

\section{Ferritin}

Die höchste Sensitivität und Spezifität zur Detektion des Eisenmangels hat die Messung des Serumferritinwerts [4,5]. Ferritinwerte $<20 \mu \mathrm{g} / \mathrm{l}$ sind beweisend für einen Eisenmangel, unabhängig vom Hämoglobinwert. Ferritinwerte zwischen $20-50 \mu \mathrm{g} / \mathrm{l}$ werden als Grauzone angesehen, das heißt, auch wenn bei diesen Werten noch geringe Eisenreserven vorhanden sind, geht man davon aus, dass eine feste Zahl von Frauen bei diesen Werten bereits Eisenmangelsymptome aufweisen. Sind die Ferritinwerte im Normbereich ( $>50 \mu \mathrm{g} / \mathrm{l})$, kann eine Eisenmangelanämie praktisch ausgeschlossen werden, außer es liegt gleichzeitig der Verdacht einer Infektion vor. In diesem Fall können die Ferritinspiegel falsch normal sein, da Apoferritin ähnlich wie das C-reaktive Protein ein Akutphasenprotein ist und bei Infektionen wie auch Entzündungsreaktionen (z. B. postoperativ), ansteigt. Man geht davon aus, dass die Serumferritinwerte ca. 6 Wochen nach Operationen oder Geburten die Eisenspeicher wieder korrekt darstellen. Bei Verdacht auf das gleichzeitige Bestehen eines Eisenmangels und einer Anämie sollte stets das Vorliegen einer Infektion oder Entzündung (CRP-Messung) ausgeschlossen werden, um eine klare Aussage über den Eisenstatus treffen zu können. In speziellen Fällen kann die Eisendiagnostik mit verschiedenen Parametern ergänzt werden.

\section{Ursachen von Eisenmangel}

$\nabla$

Frauen haben naturgemäß ein deutlich höheres Risiko für Eisenmangelzustände als Männer. Frauen mit regelmäßiger Menstruation zeigen eine ca. 10-mal höhere Prävalenz für Eisenmangel als gleich alte Männer, daneben kann gezeigt werden, dass beispielsweise bei Blutspendern fast nur Frauen Ferritinwerte $<20 \mathrm{ng} / \mathrm{ml}$, also leere Eisenspeicher aufweisen. Der Grund dafür liegt in den regelmäßigen Blutbzw. Eisenverlusten bei der Menstruation bei gleichzeitig oft ungenügender bzw. nicht ausreichender täglicher Eisenzufuhr über die Nahrung. Während bei Männern der tägliche Eisenverlust via Blut- und Stoffwechsel ca. $1,5 \mathrm{mg} /$ Tag beträgt, liegt dieser bei Frauen um ca. $0,5 \mathrm{mg} /$ Tag höher, also etwa $2 \mathrm{mg} / \mathrm{Tag}$, bei „normaler“ Menstruation ( $<80 \mathrm{ml} /$ Monat). Bei Frauen ohne Menstruation, beispielsweise nach Hysterektomie oder in der Postmenopause ist der Eisenverbrauch pro Tag mit dem von Männern vergleichbar. Bei verstärkter Menstruation (Hypermenorrhö), können die Blutverluste allerdings bis zu $400 \mathrm{ml}$ (!) pro Monat betragen, was einem Eisenverlust von ca. $200 \mathrm{mg}$ entspricht $[6,7]$. Risikofaktoren für eine übermäßige Menstruation sind beispielsweise Myome, Adenomyosis uteri, Endometriumhyperplasien und -polypen als uterine Faktoren, aber auch Gerinnungsstörungen wie typischerweise von-Willebrand-Syndrom oder Thrombopathien. Bedenkt man, dass eine erwachsene Frau ca. 300 mg Eisenspeicher von 2,3 g Gesamtkörpereisen aufweist, ist leicht erklärbar, wie starke Menstruationsblutungen zu einer Entleerung der Speicher führen können. 70\% der Frauen mit Blutverlusten über $80 \mathrm{ml} /$ Monat weisen einen Eisenmangel mit oder ohne Anämie auf.

\section{Gynäkologische Blutung als Ursache des Eisenmangels und der Eisenmangelanämie $\nabla$}

Gynäkologische Blutungen, die einen Eisenmangel verursachen, sind rezidivierende auftretende Hypermenorrhöen, Menorrhagien oder Metrorrhagien. In der englischen Definition werden diese zusammengefasst unter dem Begriff „heavy menstrual bleeding“. Es ist seit vielen Jahren nachgewiesen, dass mit zunehmendem menstruellem Blutverlust die Rate an Anämien signifikant ansteigt. 


\section{Prevention of Iron Deficiency and Treatment}

$\nabla$

Ideally, women can compensate for a loss of iron by ensuring sufficient iron intake in their diet. But nutritional iron intake depends on the iron content of the food consumed, the ingested amount as well as the individual capacity for intestinal iron absorption and the bioavailability of the iron. Iron-rich food such as meat contains up to $2 \mathrm{mg} / 100 \mathrm{~g}$, but its absorption in the intestine ranges from $1-20 \%$, depending on whether the food is of vegetable or animal origin. A daily requirement of $2 \mathrm{mg}$ iron/day can be met by the consumption of $300 \mathrm{~g}$ meat/fish or of $1000 \mathrm{~g}$ soy or $5000 \mathrm{~g}$ spinach. This shows that compensating for high levels of iron loss by nutritional means alone is unrealistic given today's eating habits and the amounts consumed $[9,10]$. Moreover, knowledge about the iron content in foods is very low in the general population, i.e. most people do not know which foods are iron-rich and how much of them they should consume. We have developed an app for cell phones (MyIronfriend ${ }^{\mathrm{TM}}$ ) which offers information to women to help them when buying food (www. myironfriend.com).

Therapy consists of oral iron supplementation (tablets or drops/ syrup) or intravenously administered iron preparations. Oral iron supplements ( $₫$ Table 2 ) are available as iron(II) salts or iron(III) complexes. Depending on their composition, absorption of oral preparations is between 1 and $8 \%$. Oral administration of $80 \mathrm{mg} /$ day corresponds to around $8 \mathrm{mg}$ iron absorbed per day. Interventional studies (oral iron vs. placebo) have shown that daily doses of $20 \mathrm{mg}$ iron(II) salts can significantly improve iron deficiency symptoms [11]. The gastrointestinal side effects of oral iron supplements increase with higher dosages due to the toxic oxidative effect of iron on cells. This generally becomes more acute with daily doses $>100 \mathrm{mg} /$ day, which results in decreasing compliance. Irrespective of the preparation administered, around $20 \%$ of women stop taking oral iron supplements sooner or later [12]. Gastrointestinal tolerance of iron(III) complexes is generally better but absorption is poorer. In symptomatic women with iron deficiency who do not respond to oral iron supplements ( $\bullet$ Table 3), iron can be administered as an intravenous iron preparation (iron sucrose, ferric carboxymaltose, iron dextran, iron gluconate). Iron sucrose and ferric carboxymaltose preparations are the most studied i.v. iron supplements used to treat women. These preparations are safe even at high dosages (ferric carboxymaltose up to $1000 \mathrm{mg} /$ single dose) [14]. The rate of side effects is around 5\% (dizziness, flushing, muscle pains, flu-like symptoms); severe allergic reactions to iron sucrose or ferric carboxymaltose are very rare. It is important to avoid any extravasation of parenteral iron as this can result in persistent skin discolouration. The effectiveness of iron sucrose and ferric carboxymaltose to treat women who have given birth, pregnant women (iron sucrose) and women who suffer from heavy uterine bleeding has been investigated in large randomised studies [15]. A recent study has shown a significant improvement of fatigue in women with iron

Table 2 Oral iron therapy.

Preventative dosage: $30-80 \mathrm{mg} /$ day

Therapeutic dosage: $80-200 \mathrm{mg} /$ day

Iron(II) salts or iron(III) complex

$3 \mathrm{mg} / \mathrm{kg}$ (1-2/day), 4 weeks

- Goal: increase $1 \mathrm{~g} / \mathrm{dl}$ (2-4 weeks)

- Duration of therapy depends on $\mathrm{Hb}$ and Fe stores

- Duration of therapy depends on co-morbidity/blood loss...
Es konnte in einer Studie an 330 Patientinnen gezeigt werden, dass bei einem menstruellen Blutverlust von $61-80 \mathrm{ml}$ pro Zyklus die Anämierate $10,3 \%$ beträgt, während sie bei einem menstruellen Blutverlust zwischen $161-240 \mathrm{ml}$ bei $50 \%$ liegt [7].

In einer weiteren Studie wurde gezeigt, dass bei einer Definition eines Eisenmangels (Hämoglobin unter $12 \mathrm{~g} / \mathrm{dl}$ und einem Ferritinwert unter $16 \mathrm{ng} / \mathrm{dl}$ ) sich bei einem Blutverlust unter $20 \mathrm{ml}$ eine Prävalenz der Eisenmangelanämie von $0 \%$ fand, während bei einem Blutverlust von $60-80 \mathrm{ml}$ die Prävalenz $17 \%$ und bei einem Blutverlust von über $100 \mathrm{ml}$ die Prävalenz 26\% betrug [6].

Gynäkologische Blutungen, die durch Erkrankungen wie Adenomyosis, Uterus myomatosus oder Endometriumhyperplasien verursacht werden, führen häufig zu erheblichen Eisenmangelanämien [8]. In Studien für die Zulassung einer hormonellen Therapie zur Behandlung der Hypermenorrhö konnte in den Ausgangsgruppen von 231 Patientinnen mit Hypermenorrhö mit der sehr spezifischen AlkalinHämatin-Methode in einer 90-Tage-Referenzmethode (WHO) ein Blutverlust von im Mittel $640 \mathrm{ml}$ nachgewiesen werden. Die Menge des Blutverlusts korrelierte gut mit niedrigen Hämoglobin- und Ferritinwerten [8].

\section{Prävention und Therapie des Eisenmangels \\ $\nabla$}

Idealerweise kann eine Frau durch ausreichende Eisenaufnahme mit der Nahrung ihre Eisenverluste ausgleichen. Die Eisenaufnahme mit der Nahrung hängt aber vom Eisengehalt des Lebensmittels ab, der eingenommenen Menge und schließlich der individuellen Resorption des Eisens im Darm und der Bioverfügbarkeit des Eisens. Eisenreiche Nahrungsmittel wie Fleisch enthalten bis $2 \mathrm{mg} / 100 \mathrm{~g}$, die Absorption im Darm schwankt aber von 1-20\%, je nachdem, ob es sich um tierische oder pflanzliche Nahrung handelt. Ein Tagesbedarf von $2 \mathrm{mg}$ Eisen/Tag wird von $300 \mathrm{~g}$ Fleisch/Fisch abgedeckt, aber von ca. $1000 \mathrm{~g}$ Sojabohnen oder $5000 \mathrm{~g}$ Spinat. Dies zeigt, dass der Ausgleich höherer Eisenverluste mittels Nahrung bei den heutigen Essgewohnheiten und Mengen unrealistisch ist $[9,10]$. Hinzu kommt, dass die Kenntnis in der Bevölkerung über den Eisengehalt der Nahrung meist sehr gering ist, d. h. sie weiß gar nicht, welche Lebensmittel eigentlich eisenreich sind und wie viel sie einnehmen sollte. Eine von uns entwickelte Handyapplikation („MyIronfriend ${ }^{\mathrm{TM}}$ “) soll die Frau hierbei unterstützen und zur Selbsthilfe beim täglichen Einkauf instruieren (www. myironfriend.com).

Therapeutisch können sowohl orale Eisenpräparate (Tabletten oder Tropfen/Sirup) oder intravenöse Eisenpräparate verwendet werden. Orale Eisenpräparate ( $\odot$ Tab.2) sind als Fe-II-Salze oder Fe-III-Komplexe erhältlich, wobei die Resorption der oralen Präparate je nach Zusammensetzung zwischen 1-8\% beträgt. Bei einer 80 -mg-Tablette/Tag entspricht dies knapp $8 \mathrm{mg}$ Eisenresorption/Tag. Anhand von Interventionsstudien (Eisen oral vs. Placebo), kann gezeigt werden, dass bereits Tagesdosen von 20 mg Fe-(II-)Salzen zu einer signifikanten Verbesserung von Mangelsymptomen führen [11]. Mit zunehmender Dosierung steigen die gastrointestinalen Nebenwirkungen bei oralem Eisen aufgrund der toxisch oxidativen Wirkung des Eisens an den Zellen. Meist bei Tagesdosen > $100 \mathrm{mg} / \mathrm{Tag}$, was zu einer abnehmenden Compliance führt. Unabhängig vom Präparat brechen fast $20 \%$ der Frauen eine orale Eisentherapie früher oder später ab [12]. Eisen-III-Komplexe zeigen im Allgemeinen eine bessere gastrointestinale Verträglichkeit, werden aber in geringerem Maße resorbiert. Bei Eisenmangelzuständen, die nicht auf orales Eisen ansprechen ( Tab. 3), kann auf ein intravenöses Eisenpräparat (Eisensucrose, Eisencarboxymaltose, Eisendextran, Eisengluconat) gewechselt werden. Im Bereich der Gynäkologie liegen bisher die meisten Er- 
Table 3 Potential indications for i. v./parenteral iron administration.

\begin{tabular}{|c|c|c|}
\hline $\begin{array}{l}\text { No response (Hb increas } \\
\text { intake due to: } \\
\text { - severe chronic iron de } \\
\text { - poor absorption } \\
\text { - intolerance } \\
\text { - lack of compliance } \\
\text { - co-morbidities (Crohr }\end{array}$ & $\begin{array}{l}\text { /dl/day or }<2 \mathrm{~g} / \mathrm{dl} \text { } \\
\text { se, renal disease, } \mathrm{s}\end{array}$ & $\begin{array}{l}4 \text { days) to oral iron } \\
\text { etc.) }\end{array}$ \\
\hline $\begin{array}{l}\text { Note: Iron(II) salts have } \\
\text { (III) complexes. The rate } \\
\text { Higher oral dosages sho } \\
\text { day; iron(II) salts should } \\
\text { complexes can be taken } \\
\text { greatly reduced and the } \\
\text { gastrointestinal inflamm }\end{array}$ & $\begin{array}{l}\text { tes of adverse side } \\
\text { se side-effects de } \\
\text { Iministered as frac } \\
\text { e taken on an emp } \\
\text { with food. The at } \\
\text { dverse side effects }\end{array}$ & $\begin{array}{l}\text { ts compared to iron } \\
\text { on the daily dosage. } \\
\text { red doses during the } \\
\text { mach while iron(III) } \\
\text { ion of oral iron is } \\
\text { her in women with }\end{array}$ \\
\hline Symptom & $\begin{array}{l}\text { Iron deficiency } \\
\text { + anaemia }\end{array}$ & $\begin{array}{l}\text { Iron deficiency } \\
\text { without anaemia }\end{array}$ \\
\hline Fatigue & $3.0 \pm 1.0(431)$ & $3.0 \pm 0.9(576)$ \\
\hline Poor concentration & $2.1 \pm 1.2(409)$ & $2.0 \pm 1.2(541)$ \\
\hline Headache & $1.2 \pm 1.2(406)$ & $1.1 \pm 1.2(531)$ \\
\hline Pale skin & $1.7 \pm 1.2(413)$ & $0.7 \pm 0.9(518)$ \\
\hline Hair loss & $1.1 \pm 1.2(399)$ & $1.2 \pm 1.3(536)$ \\
\hline Dyspnoea & $1.1 \pm 1.2(402)$ & $0.5 \pm 0.9(513)$ \\
\hline Insomnia & $1.1 \pm 1.2(407)$ & $1.1 \pm 1.3(527)$ \\
\hline Restless legs syndrome & $0.7 \pm 1.0(378)$ & $0.7 \pm 1.1(507)$ \\
\hline
\end{tabular}

Prevalence (\%) of various symptoms in women with iron deficiency.

With and without anaemia $(n=1007)$. [13]

Table 4 In vitro iron administration - practical application.

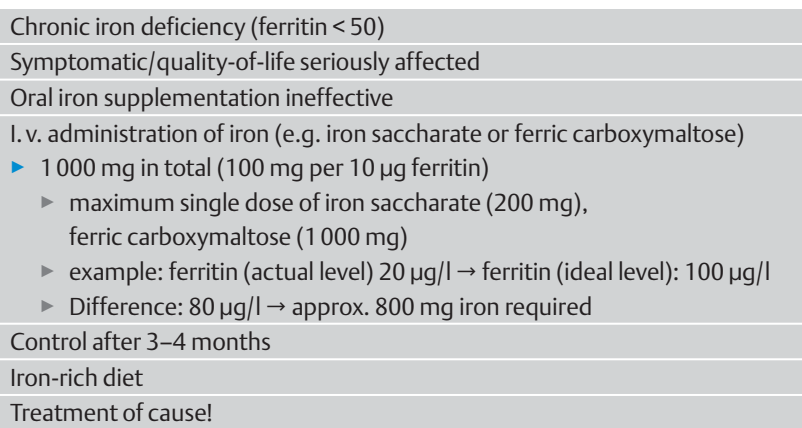

deficiency but without anaemia who took iron sucrose or ferric carboxymaltose compared to placebo [2]. It should be noted that after parenteral administration of iron, ferritin levels increase to high normal values (up to $700 \mathrm{ng} / \mathrm{ml}$ ), but these do not reflect the actual iron stores. To obtain a correct idea of ferritin levels, they need to be measured again around 12-16 weeks after i.v. administration of iron ( $\bigcirc$ Table 4 and Fig. 1).

\section{Sustainability of Iron Therapy}

Iron therapy only makes sense if the cause of the iron deficiency or increased iron depletion is also treated. If the cause of depletion is not corrected at the same time, the patient may present with empty iron stores a few months after i.v. iron therapy. Vegetarians who menstruate and have a low dietary iron intake can generally not replenish or maintain their iron stores. The same applies to women who periodically have high iron loss (menstruation, blood donors) or depletion (competitive athletes, pregnant women). Additional measures carried out concomitantly with iron therapy to treat the cause of bleeding disorders and investi-

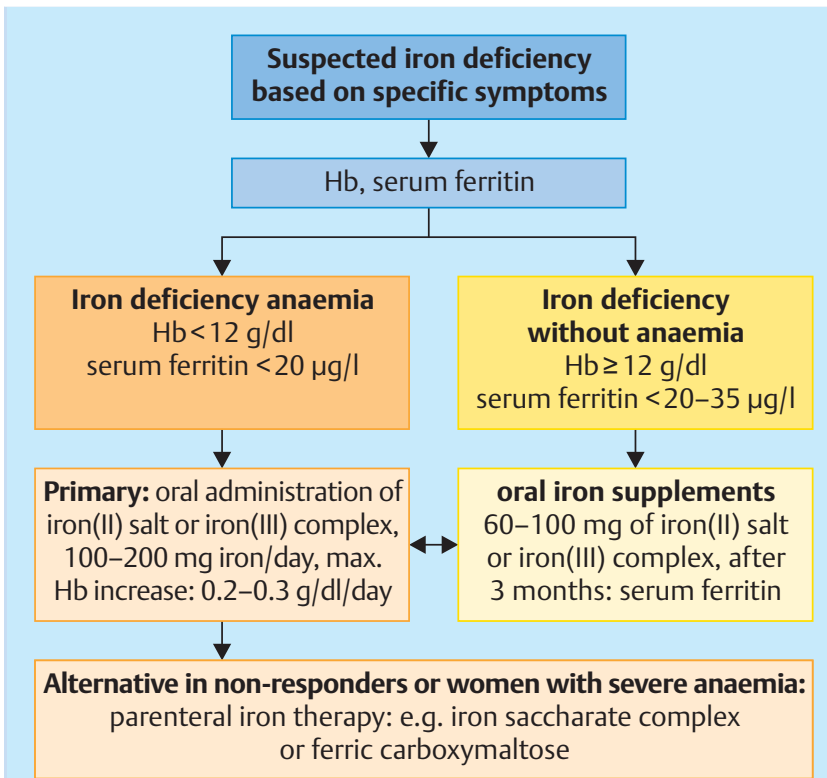

Fig. 1 Algorithm for the diagnosis and treatment of iron deficiency in premenopausal women. fahrungen mit den Eisensucrose- und -carboxymaltose-Präparaten vor. Diese Präparate zeichnen sich vor allem durch ihre hohe Sicherheit auch bei hohen Dosierungen aus (Eisencarboxymaltose bis $1000 \mathrm{mg} /$ Einzelgabe) [14]. Die Rate an unerwünschten Nebenwirkungen liegt bei ca. 5\% (Schwindel, Wärmegefühl, Gliederschmerzen, grippeähnliche Symptome), schwere allergische Reaktionen sind bei Eisensucrose und Eisencarboxymaltose sehr selten. Unbedingt sollten Paravasate bei der parenteralen Eisengabe vermieden werden, da es danach zu persistierenden Hautverfärbungen kommen kann. Mittlerweile liegen große randomisierte Studien zur Effektivität von Eisensucrose und -carboxymaltose bei Frauen im Wochenbett, in der Schwangerschaft (Eisensucrose) und bei starken uterinen Blutungen vor [15]. Des Weiteren konnte kürzlich sowohl für Eisensucrose als auch Eisencarboxymaltose eine deutliche Verbesserung von Fatigue bei Frauen mit Eisenmangel ohne Anämie im Vergleich zu Placebo gezeigt werden [2]. Zu beachten ist, dass die Ferritinwerte nach i.v. Eisengaben auf hochnormale Werte ansteigen (bis $700 \mathrm{ng} / \mathrm{ml}$ ), die nicht den tatsächlichen Eisenspeicher reflektieren. Man geht davon aus, dass die Ferritinwerte etwa 12-16 Wochen nach der i.v. Eisengabe wieder gemessen werden sollten ( Tab. 4 und Abb. 1).

\section{Nachhaltigkeit der Eisentherapie}

Eine Eisentherapie macht nur Sinn, wenn gleichzeitig die Ursache des Eisenmangels bzw. der Eisenverluste behandelt wird. So kann eine Frau schon einige Monate nach einer i.v. Eisentherapie wieder leere Eisenspeicher aufweisen, wenn nicht gleichzeitig Eisenverluste korrigiert werden. Vegetarierinnen, die menstruieren und wenig Eisen mit der Nahrung aufnehmen, können beispielsweise meistens nicht ihre Eisenspeicher auffüllen oder die aufgefüllten Speicher aufrecht erhalten. Ebenso gelingt das nicht bei Frauen mit periodisch hohen Eisenverlusten (Menstruation, Blutspenderinnen) oder Verbrauch (Leistungssportlerinnen, Schwangere). Daher ist parallel zur Eisen- 
Table 5 Potential measures to reduce blood loss/iron loss.

$\begin{array}{ll}\text { Medications } & \text { Effect } \\ \text { - Gestagen-releasing coil, gestagen pill } & \begin{array}{l}\text { reduces menstruation } \\ \text { menstrual cycle regulation } \\ \text { Cyklokapron during men- } \\ \text { - Fibrinolysis inhibitors }\end{array} \\ \begin{array}{ll}\text { struation (1000 mg/dose) } \\ \text { affects prostaglandin }\end{array} \\ \begin{array}{ll}\text { Surgery } & \text { synthesis }\end{array} \\ \begin{array}{l}\text { Effect } \\ \text { - Mydometrial ablation, thermoablation }\end{array} & \begin{array}{l}\text { reduces blood loss } \\ \text { reduces blood loss }\end{array} \\ \text { - Hysterectomy (last choice after other } & \text { no menstruation } \\ \text { alternatives have failed) } & \end{array}$

gation/treatment by a gynaecologist or other physician (internal specialist, haematologist, nutritionist) are therefore very important ( $\bullet$ Table 5). Key messages are summarized in $\bullet$ Table 6.

\section{Conflict of Interest}

\section{$\nabla$}

C. Breymann ist medizinischer Berater im Bereich Eisentherapie in der Gynäkologie bei Vifor International/Schweiz; J. W. Dudenhausen hat von Vifor gesponsorte Seminare zur Anämie in der Geburtshilfe geleitet.

\section{References}

1 Hercberg S, Preziosi P, Galan P. Iron deficiency in Europe. Public Health Nutr 2001; 4: 537-545

2 Krayenbuehl P, Battegnay C, Breymann C et al. Intravenous iron for the treatment of fatigue in non-anemic premenopausal women with low ferritin concentration. Blood 2011; 22: 3222-3227

3 Verdon F, Burnand B, Fallab Stubi C-L et al. Iron supplementation for unexplained fatigue in non-anaemic women: double blind randomised placebo controlled trial. BMJ 2003; 326: 1124-1128

4 Wick M, Pinggera W, Lehmann P. Ferritin im Eisenstoffwechsel. Diagnostische Strategien. Wien, New York: Springer Verlag; 1991

5 Wick M, Pinggera W, Lehmann P. Klinik und Labor. Eisenstoffwechsel und Anämien. Wien, New York: Springer Verlag; 2002

6 Gao J, Zeng S, Sun B. Menstrual blood loss and haematologic indices in healthy Chinese women. J Reprod Med 1992; 7: 145-153

7 Janssen C, Scholten P, Heintz A. Reconsidering menorrhagia in gynecological practice. Is a 30-year old definition still valid? European J Obstet Gynecol Reprod Med 1998; 78: 69-72

8 Fraser I, Römer T, Parke $S$ et al. Effective treatment of heavy and prolonged menstrual bleeding with an oral contraceptive containing estradiol valerate and dienogest; a randomized, double blind Phase III trial. Hum Reprod 2011; 26: 2698-2708

9 Kennedy E, Meyers L. Dietary reference intakes: development and uses for assessment of micronutrient status of women-a global perspective. Am J Clin Nutr 2005; 81 (Suppl.): 1194S-1197S

\section{Table 6 Key messages.}

Iron deficiency and anaemia

- Causes of morbidity \& dysfunction depending on severity

- Tests are important if there is a suspicion of iron deficiency:

- ferritin level (caution: false normal values if infection is present)

- therapy only after iron deficiency has been diagnosed and if the patient is symptomatic!

- treat existing iron deficiency

- investigate causes and co-morbidities

- Therapy

> oral iron (iron[II] or iron[III]), 80-100 mg/day (4-8 weeks)

- alternative: parenteral iron administration (e.g. iron sucrose, ferric carboxymaltose) therapie die Ursachenbehandlung von Blutungsstörungen wie auch unterstützende Maßnahmen durch den Gynäkologen und Kollegen weiterer Fachdisziplinen (z. B. Internisten, Hämatologen, Ernährungsberater) von großer Wichtigkeit ( Tab.5). Die wichtigsten Merkpunkte sind in $\odot$ Tab. 6 zusammengefasst.

\section{Interessenkonflikt}

\section{$\nabla$}

C. Breymann ist medizinischer Berater im Bereich Eisentherapie in der Gynäkologie bei Vifor International/Schweiz; J. W. Dudenhausen hat von Vifor gesponsorte Seminare zur Anämie in der Geburtshilfe geleitet.

10 Akabas SR, Dolins K. Micronutrient requirements of physically active women: what can we learn from iron? Am J Clin Nutr 2005; 81: 1246S-1251S

11 Martius F. Eisenmangel ohne Anämie: ein heisses Eisen. Swiss Medical Weekly 2009; 9: 294-299

12 Milman N, AggerA, Nielson O. Iron supplementation during pregnancy. Dan Med Bull 1991; 38: 471-476

13 Beglinger C, Breymann C. Behandlung von Eisenmangel. Schweiz Med Forum 2010; 30: 50

14 Muñoz M, Breymann C, García-Erce JA et al. Efficacy and safety of intravenous iron therapy as an alternative/adjunct to allogeneic blood transfusion. Vox Sang 2008; 94: 172-183

15 Breymann C, Honegger C, Holzgreve Wet al. Diagnosis and treatment of iron deficiency anaemia during pregnancy and postpartum. Arch Gynecol Obstet 2010; 282: 577-580

16 Raspe F, Breymann C. Diagnostik und Therapie der Eisenmangelanämie in Schwangerschaft und Wochenbett - eine Befragung geburtshilflicher Kliniken in der Schweiz. Geburtsh Frauenheilk 2011; 71: 595600

Deutschsprachige Zusatzinformationen online abrufbar unter: www.thieme-connect.de/ejournals/toc/gebfra. 